Renata Szczepanik $k^{*}$

\title{
PROWADZENIE BADAŃ NAUKOWYCH W WARUNKACH IZOLACJI WIĘZIENNEJ
}

\section{WPROWADZENIE}

Badania prowadzone w polskich zakładach karnych mają stosunkowo skromną historię i dorobek. Przez wiele lat jednostki penitencjarne stanowiły bowiem zamknięty i niedostępny obszar wiedzy oraz działań społecznych i podlegały ścisłej tajemnicy państwowej ${ }^{1}$. Jako tabu traktowane były wszystkie aspekty funkcjonowania więziennictwa. Naczelnym zadaniem pracy służby więziennej PRL (SW) było skuteczne odseparowanie więźniów od reszty społeczeństwa na długie lata. Jeśli zaś chodzi o fundament, na którym opierano bezpieczeństwo w samym więzieniu, to było nim uznanie więźnia za niebezpiecznego wroga (politycznego). Funkcjonariusze SW zostali zmilitaryzowani, a więźniowie poddawani bezwzględnej uległości i tresurze. Taki układ pozycji i sił powodował, że jednostki penitencjarne pozostawały w przewlekłej sytuacji buntu więźniów lub realnego jego ryzyka wystąpienia. To z kolei implikowało zaostrzanie regulaminu dyscyplinarnego oraz wprowadzanie rozmaitych kar drastycznie łamiących prawa człowieka. Na terenie zakładów karnych sprzyjało to i pogłębiało patologie społeczne, a jednocześnie powodowało budowanie „skutecznego" i szczelnego systemu zabezpieczeń przed ujawnianiem nieprawidłowości oraz wzrost hermetyzacji środowiska więziennego.

W okresie PRL istniały dwa obrazy rzeczywistości więziennej. Oficjalny, prezentowany zazwyczaj w branżowym czasopiśmie „Gazeta Penitencjarna” i na różnego rodzaju oficjalnych naradach, gdzie pokazywano sukcesy w resocjalizacji więźniów, ich coraz szersze zatrudnienie, podnoszenie poziomu wykształcenia funkcjonariuszy oraz zwiększenie ich „fachowości”. W obrazie tym nie było praktycznie żadnej skazy, co najwyżej czasami ubolewano nad brakiem dyscypliny

* Dr, adiunkt, Pracownia Pedagogiki Specjalnej, Wydział Nauk o Wychowaniu, Uniwersytet Łódzki, ul. Smugowa 10/12, 91-433 Łódź; szczepanik@uni.lodz.pl.

1 Paweł M o c z y dło w s k i (2003: 89) parafrazuje określenie z Archipelagu Gułag Aleksandra Sołżenicyna, że ,więzienia to rozrzucone, samotne, trudno dostępne wyspy. I dostać się tam i wydostać stamtąd trudno". 
wśród funkcjonariuszy lub podnoszono problemy patologii wśród więźniów. Istniał również inny obraz, prawdziwy, ale prezentowany tylko wąskiemu gronu ważniejszych funkcjonariuszy ${ }^{2}$.

Właściwie dopiero w latach 90. powstają dość liczne publikacje naukowe, które poświęcone są problematyce penitencjarnej. Jednakże nawet współcześnie, mimo wyraźnych przeobrażeń $\mathrm{w}$ organizacji i strukturze jednostek penitencjarnych oraz dostępności dla naukowców, więzienie stanowi specyficzne i trudne miejsce badań. Problemy te stanowią splot i kumulację rozmaitych determinantów, których korzenie z jednej strony tkwią głęboko w historyczno-politycznych uwarunkowaniach „mentalności” penitencjarnej oraz paramilitarnym charakterze SW, a z drugiej w czynnikach psychospołecznych związanych z izolacją społeczną jednostki.

Celem niniejszego artykułu jest charakterystyka trudności prowadzenia badań naukowych w więzieniu oraz ukazanie ich uwarunkowań - zarówno tkwiących w czynnikach badanego fragmentu rzeczywistości społecznej, jak i w kwestiach metodologicznych. Szczególną uwagę pragnę poświęcić dwóm krańcowo odmiennym od siebie procedurom badawczym, jakimi są badania ankietowe oraz obserwacja uczestnicząca. Zastosowanie w badaniach naukowych na terenie więzienia pierwszej i drugiej metody implikuje wiele różnorodnych problemów - od organizacji badań, doboru oraz właściwości próby badawczej, po dylematy etyczne towarzyszące sposobom zbierania danych. Nieuwzględnienie i bagatelizowanie tych trudności poddaje w wątpliwość rzetelność uzyskanych wyników badań. Zagadnienie to dotyczy w podobnym stopniu badaczy sięgających zarówno po metody ilościowe, jak i jakościowe, choć specyficzne „pułapki” metodologiczne dla obu tych podejść tkwią w różnych obszarach struktury więziennej.

\section{HISTORYCZNO-POLITYCZNY KONTEKST UWARUNKOWAŃ TRUDNOŚCI PROWADZENIA BADAŃ NAUKOWYCH NA TERENIE ZAKLADÓW KARNYCH - ZARYS PROBLEMU}

Na przestrzeni ostatniego półwiecza polskie więziennictwo przeżyło ogromne zmiany. Dotyczyły one wszystkich aspektów jego funkcjonowania. Pierwszym przełomowym momentem był rok 1956, kiedy częściowo ujawniono rzeczywistość więziennictwa z czasów stalinowskich. Na światło dzienne wydostały się informacje dotyczące okrutnego traktowania więźniów, zwłaszcza politycznych. Po 1956 r. postępowanie z osobami pozbawionymi wolności nie cechowało się już tak dramatyczną represyjnością i bezwzględnością, choć dalekie było od realizowania swoich funkcji resocjalizacyjnych. Miały miejsce incydentalne próby wprowadzania nowatorskich rozwiązań w systemie odbywania kary pozbawienia

\footnotetext{
2 Problematyka ta szczegółowo opisana jest m.in. w artykule Renaty S z c z e p a n i k (2009).
} 
wolności, ale pozostawały one na marginesie głównego nurtu polityki penitencjarnej i miały charakter eksperymentalny (jak np. zakład karny dla młodocianych w Szczypiornie - o czym będzie mowa w dalszej części opracowania). Istotne i systemowe zmiany w więziennictwie, zwłaszcza na gruncie postępowania z osobami pozbawionymi wolności, miały miejsce dopiero w latach 1981 i 1989.

W okresie PRL wszelkie nieprawidłowości i nadużycia objęte były ścisłą tajemnicą. Na przekazywane funkcjonariuszom informacje służbowe nałożony był bezwzględny zakaz upowszechniania poza środowisko służby więziennej. Określona wiedza pozostawała jedynie w ścisłym gronie zawodowym. Problematyka stosunków panujących wewnątrz zakładów karnych była nieznana opinii publicznej do końca lat $80 .^{3}$ Niemożliwe było wejście na teren zakładu karnego (dalej niż sala widzeń) nikomu spoza ,zaufanego” grona zainteresowanych. Jakiekolwiek próby opisu jednostek penitencjarnych wymagały zgody samego szefa więziennictwa, a tematy podjęte w badaniu nie mogły dotyczyć sytuacji więźniów. Cenzurze i ocenie podlegały metody i narzędzia badawcze oraz przebieg badań (Moczydłowski 1989).

O hermetyczności więziennictwa i wynikających stąd konsekwencjach pisał w roku 1986 Teodor S z y m a n o w s k i:

[...] składnikiem tradycji i praktyki penitencjarnej w PRL jest pewna hermetyczność więziennictwa wobec społeczeństwa. Przejawia się to w przeroście ponad oczywistą potrzebę, tajności pracy w więziennictwa, często uzewnętrzniającej się niechęci do nieskrępowanego wpuszczania na teren zakładów penitencjarnych przedstawicieli innych zainteresowanych tą problematyką instytucji, np. naukowych, usiłowaniu wpływania na zakres i treść publikacji poświęconych sprawom więziennictwa, niedopuszczanie do działania na terenie zakładów niezależnych od administracji organizacji społecznych oraz przedstawicieli krytycznie oceniających działalność więziennictwa. Potęguje to bardzo silną solidarność wewnątrzgrupową w ramach SW i jednocześnie nieufność społeczeństwa do jej pracy w zakładach karnych. Następstwem tej sytuacji i takich nastawień była podatność pewnych środowisk społecznych na

3 Dopiero pod koniec lat 80. obserwować można pewne zmiany w tym zakresie. Przykładem mogą być materiały z narady przeprowadzonej w Centralnym Zarządzie Zakładów Karnych (CZZK) 26 stycznia 1987 r. z dyrektorami Oddziałów Zarządów Zakładów Karnych (dokument znajduje się w archiwum Aresztu Śledczego w Łodzi). Wśród wniosków dotyczących stanu ówczesnego więziennictwa wskazywano m.in. na to, że w środowisku więziennym utarty jest totalitaryzm i uniformizm przejawiające się zarówno w myśleniu, jak i działaniu. Wśród kadry popularny jest pogląd, że więziennictwa nie warto reformować, bo i tak po okresie nowinek wszystko powróci do starej formy. Podnoszono też zarzut, iż nie korzysta ono z dorobku nauki. Na tej samej naradzie dyrektor CZZK stwierdził, że należy zerwać z dotychczasową praktyką izolowania się od społeczeństwa. Według niego „po wyjęciu więziennictwa spod ścisłej cenzury należy oczekiwać bardzo dużego zainteresowania więziennictwem w publikatorach”. Dodał on, że „dotychczasowy bojkot prasy i nauki był ze szkodą dla więziennictwa. Należy szeroko podjąć współpracę z instytucjami z zewnątrz, jak: Patriotyczny Ruch Odrodzenia Narodowego (PRON) czy rady narodowe. We współpracę angażować również ciekawych ludzi i zapraszać na spotkania z funkcjonariuszami i skazanymi”. Niewątpliwie jest to przykład próby zerwania z izolacją społeczno-zawodową i zmiany postrzegania służby przez społeczeństwo. 
niejednokrotnie fantastyczne opowieści dotyczące działalności więziennictwa (obok rzetelnej krytyki) rozpowszechniane w roku 1981 (S z y m a n ow ski 1986: 181).

W tym samym opracowaniu Szymanowski pisze również o zniweczeniu planów przeprowadzenia badań na temat statutu społeczno-zawodowego funkcjonariuszy SW. Badania te miały być zrealizowane na początku lat 80 ., ale nie doszły do skutku. Należy sądzić, że decyzja o odwołaniu badań została podjęta na skutek nacisku władz więziennictwa.

Problematyka funkcjonowania zawodowego funkcjonariuszy SW nie była podejmowana przez cały okres PRL mimo nacisków i postulatów środowiska naukowego objęcia badaniami m.in. personelu penitencjarnego w kontekście podnoszenia jakości interakcji społecznych na terenie więzienia (por. Jarzę b o w s k a-B a zi a k 1973). Zasadniczą przyczyną marginalizowania społecznego i izolowania zawodu więziennika było upolitycznienie systemu penitencjarnego. Do służby przyjmowane były osoby z podstawowym wykształceniem, nieposiadające umiejętności zawodowych, co sprzyjało buntom więźniów, zamieszkom i silnie wpisywało się w realizację polityki represyjności penitencjarnej PRL.

$\mathrm{Na}$ początku lat 90 . więziennictwo polskie podlega wyraźnym reformom. Ich przeprowadzenia podjął się wspomniany wcześniej Paweł Moczydłowski. Naukowo zajmował się kryminologią i nie pracował wcześniej w wymiarze sprawiedliwości. Jego zamierzeniem było zbudowanie takich relacji między skazanymi a funkcjonariuszami, które prowadziłyby do zlikwidowania chronicznego napięcia, w jakim znajdowały się polskie więzienia w okresie powojennym. Moczydłowski uważał, że przyczyną tego napięcia było traktowanie więźniów jako wrogów, a funkcjonariusze dążyli do pełnej władzy nad nimi z powodu lęku (Moczydłowski 1994, 2003). Starał się wprowadzać w życie nowy model funkcjonowania więziennictwa oparty na humanitarnym i praworządnym traktowaniu osadzonych oraz jak najszerszym wglądzie i kontroli więziennictwa przez społeczeństwo. Jego poglądy i działania miały charakter rewolucjonizujący funkcjonowanie służby więziennej z przełomu lat 80 . i 90 . oraz stwarzały przestrzeń dla prowadzenia niezależnych badań naukowych.

\section{PRZEGLĄD I CHARAKTER BADAŃ PROWADZONYCH NA TERENIE WIĘZIENIA PRZED OKRESEM TRANSFORMACJI USTROJOWEJ}

$\mathrm{Z}$ bardzo nielicznymi wyjątkami do końca lat 90. badania w zakładach karnych prowadzone były z zastosowaniem tzw. ilościowych metod. Biorąc pod uwagę ograniczenia możliwości prowadzenia niezależnych, naukowych badań w środowisku więziennym w okresie PRL, poniżej zaprezentowane zostaną niektóre z nich ze wskazaniem mankamentów i wątpliwości, co do ich rzetelności oraz wartości poznawczych. 
Należy zaznaczyć, że w omawianym okresie dość regularne doniesienia o charakterze popularnonaukowym pojawiają się głównie na łamach branżowych czasopism, takich jak dwutygodnik „Gazeta Sądowa i Penitencjarna” i „Gazeta Penitencjarna"4. Opisy funkcjonowania więzień prezentowane na łamach czasopisma nacechowane są propagandą sukcesów odnoszonych na polu penitencjarnym, a także akcentowane są walory systemu socjalistycznego w procesie profilaktyki i resocjalizacji. Materiały te należy traktować z bardzo dużą ostrożnością, ponieważ niektóre z nich - choć o naukowym profilu - nie są wolne od politycznych zniekształceń i propagandy. Analiza przedstawionych w gazecie komunikatów $\mathrm{z}$ badań naukowych prowadzonych $\mathrm{w}$ tamtym okresie dowodzi wielu uproszczeń i fasadowości. Dominują wyniki badań stanowiące deklaracje badanych więźniów (badania ankietowe), a częstym tematem dociekań przedstawianych na łamach czasopisma są zajęcia kulturalno-wychowawcze organizowane na terenie zakładu karnego. Pewną egzemplifikacją charakteru badań oraz wniosków z nich płynących, prezentowanych $\mathrm{w}$ gazecie, są dane z artykułu: Formy wykorzystywania wolnego czasu w opinii więźniów (S k o tn i c k i 1969). W świetle przedstawianych danych więźniowie niedostatecznie korzystają z „bogatej” oferty zajęć proponowanych przez personel zakładów karnych. Autorzy badań uważają, że ciekawe i pożyteczne sposoby spędzania czasu wolnego przez więźniów na terenie zakładu karnego mogą powodować przyjęcie przez nich pewnych nawyków i ich utrwalenie, a następnie podejmowanie ich po opuszczeniu zakładu karnego. Badacze bezkrytycznie przytaczają uzyskane dane procentowe i optymistycznie zakładają, że aż 74\% więźniów będzie kontynuowało „nabyte” w zakładzie karnym sposoby spędzania czasu wolnego. Wartość podobnych wniosków poddaje w wątpliwość m.in. to, że w grupie wymienianych przez autorów badań „pożytecznych" i mogących owocować przyjęciem nawyków w przyszłości są takie sposoby na spędzanie czasu wolnego, jak ,odczyty z zakresu problematyki antyalkoholowej” i konkursy „Zgaduj-zgadula” (S k o tn icki 1969: II). Bezkrytycznie również przyjmują od badanych więźniów informacje o tym, że czują się oni zdemoralizowani i mają potrzebę reedukacji. Autorzy formułują życzeniowe wnioski, np.:

[...] stosunkowo duża liczba badanych tam więźniów dostrzega przydatność w procesie wychowawczym niektórych form organizacji wolnego czasu. Charakterystyczne jest to, że więźniowie w pozytywnej ocenie pominęli w zasadzie formy o charakterze wyraźnie rozrywkowym, a wysunęli na pierwsze miejsce te spośród nich, które faktycznie mogą przyczynić się do podlegania pozytywnych zainteresowań i przemiany ich mentalności (S k o t n i c k i 1969: II).

Czasem sposoby pozyskiwania „szczerych” informacji ze strony badanych więźniów były wręcz kuriozalne - np. byli więźniowie otrzymali na adres domowy

${ }^{4}$ Czasopismo było przeznaczone wyłącznie dla pracowników więziennictwa (,do użytku wewnętrznego") z zastrzeżeniem, aby nie udostępniać osadzonym. 
ankiety do wypełnienia. Niektórzy z nich ,nie skorzystali z anonimowości. Podali nazwiska $i$ adresy. A to co napisali - co tu dużo mówić - stanowi rzecz krzepiącą. Wszyscy bowiem [...] prowadzą normalne życie" (M a n d u le w i c z 1969). Trudno nie wątpić w rzetelność uzyskanych danych i wierzyć w to, że byli więźniowie przyznają się badaczom do nielegalnej i nieakceptowanej powszechnie aktywności społecznej.

Pod patronatem Ośrodka Badań Przestępczości Ministerstwa Sprawiedliwości (OBP MS) $)^{5}$ wydawane są „Przegląd Penitencjarny i Kryminologiczny” i „Przegląd Penitencjarny”. Podejmowana na ich łamach problematyka odnosi się do różnorodnych aspektów z zakresu kryminologii, psychologii, pedagogiki, polityki penitencjarnej i prawa na terenie Polski i innych krajów bloku socjalistycznego. Na treść większości artykułów składa się przegląd wyników badań zagranicznych - psychologicznych, pedagogicznych i socjologicznych (S i k o r a 1971). Niektórzy autorzy ${ }^{6}$ prezentują własne wyniki badań prowadzonych na terenach jednostek penitencjarnych w tamtym okresie, głównie na temat patologicznych zachowań więźniów (autoagresji) i związków między ich zachowaniem przestępczym a niektórymi właściwościami osobowościowymi. Analizowane dane pochodzą zwykle z analizy dokumentów (m.in. J a n is ze w s ka-Ta lag o 1971), ankiet od więźniów lub personelu więzienia (K o w a l s k a 1966; J a r z ę bowska-Baziak, Morawski 1972), rzadziej osobiście ${ }^{7}$ przeprowadzanych wywiadów (O strih anska 1971). Swoje miejsce znajdują też badania kryminologiczne poświęcone skuteczności resocjalizacji penitencjarnej wobec młodocianych. Ta kwestia podejmowana jest głównie przez Jadwigę Si k o rę (1963, 1967), Jacka M o r a w s k i e g o (1969) i Teodora S z y ma n o w s k i e g o (1986).

Wiele opracowań w czasopismach naukowych poświęconych problematyce penitencjarnej ma charakter sprawozdawczy i stanowi próbę opisania funkcjonujących rozwiązań organizacyjno-resocjalizacyjnych. Ramy takich opracowań nie wykraczają poza rozważania prawnicze.

Przykładem przedsięwzięcia naukowego, zasługującego na szczególną uwagę w opisywanym okresie, jest projekt Barbary Jarzębowskiej-Baziak

5 Ośrodek Badania Przestępczości Ministerstwa Sprawiedliwości powstał w 1961 r. (później został przekształcony w Instytut Badania Prawa Sądowego, a od 1990 r. w Instytut Wymiaru Sprawiedliwości).

6 Analiza zawartości pisma za lata 1967-1973 pozwala sądzić, że problematyka penitencjarna podejmowana była przez niewielką grupę uczonych. Dominują opracowania o charakterze sprawozdawczym i analizującym istniejące przepisy i regulacje prawno-penitencjarne, kryminologiczne o charakterze analiz prawniczych, w końcu psychologiczne i w najmniejszym stopniu pedagogiczne. Autorzy artykułów to najczęściej prawnicy specjalizujący się w zagadnieniach penitencjarnych i kryminologicznych oraz stosunkowo wąska grupa psychologów, pedagogów - zwykle związanych w jakiś sposób zawodowo z zakładami karnymi. Do rzadkości należały artykuły naukowców niezwiązanych bezpośrednio z praktyką penitencjarną.

$7 \mathrm{~W}$ odróżnieniu od sprawozdań z wywiadów środowiskowych przeprowadzanych na zlecenie badacza przez funkcjonariusza Milicji Obywatelskiej. 
(1972), którego rezultat jest opisany w książce Praca wychowawcza w zakładzie karnym dla młodocianych. Projekt ten miał charakter innowacyjny - zarówno w kontekście rozwiązań naukowych, jak i potencjalnych implikacji dla praktyki penitencjarnej. Materiały przedstawione w książce były rezultatem badań prowadzonych w latach 1962-1967 w zakładzie karnym w Szczypiornie (Więzienie Karne Specjalne dla Młodocianych). Zakład ten już w latach 1958-1959 był terenem eksperymentu prowadzonego ${ }^{8}$ przez Witolda i Hannę Ś wi d ó w (1961), a następnie w 1962 r. badania zostały wznowione i kontynuowane pod patronatem Ośrodka Badań Przestępczości. Uwagę zwraca warsztat badawczy J a r z ę b ow ski e j-B a zi ak (1972) i sięgnięcie przez nią po nowatorskie, jak na tamte czasy, metody zbierania danych - obok analizy dokumentów, ankiety, wywiadu oraz analizy wytworów działalności skazanych i testów, autorka przedstawia dane pochodzące z obserwacji uczestniczącej i nieuczestniczącej.

Należy jeszcze raz podkreślić, iż tego rodzaju badania należały do rzadkości w omawianym okresie rzeczywistości polityczno-społecznej. Zakład w Szczypiornie był swoistym poligonem eksperymentalnym i podlegał bezpośredniemu nadzorowi konsultacyjno-metodycznemu Ośrodka Badań Przestępczości. Funkcjonujący $\mathrm{w}$ jego ramach system wychowawczo-resocjalizacyjny nie był reprezentatywny dla praktyki więziennej, dlatego też prowadzone w nim badania psychologiczne i pedagogiczne odnosiły się jedynie do tego specyficznego i niepowtarzalnego w ówczesnych warunkach penitencjarnych zakładu.

Mimo że pojawiają się badania dotyczące funkcjonowania osób osadzonych w warunkach zakładu karnego, to zupełnie pomijany jest aspekt związany z relacjami wewnątrzspołecznymi. Eksponowane są zachowania destrukcyjne samych więźniów i niejako konsekwencje pobytu w więzieniu związane $\mathrm{z}$ wadliwym funkcjonowaniem osoby inkarcerowanej (lecz brak jest charakterystyki negatywnych czynników leżących po stronie zakładu karnego). Jeśli podstawowymi narzędziami badawczymi były kwestionariusze ankiety, zawierające pytania z kafeterią zamkniętą, to uzyskane dane nie mogły wykraczać poza hipotezy zakładane przez autora badań. Przykładem takiego podejścia metodologicznego może być praca habilitacyjna Mieczysława R u d i ka (1970): Warunki reedukacji młodocianych skazanych na krótkie kary pozbawienia wolności. Podstawowym źródłem wiedzy na temat dolegliwości odczuwanych przez młodocianych więźniów były ich opinie pochodzące z ankiety, dotyczące przeżyć i doświadczeń więziennych sprzed wielu lat (badania retrospektywne). Na tej podstawie wysnuwano wnioski o związku długości odbywania kary pozbawienia wolności z jej dolegliwością. Należy zaznaczyć, iż sam autor podkreśla, że wiele z badanych przez niego osób cechowało się głębokim poziomem demoralizacji oraz wykazywało znaczne odchylenia od normy psychicznej. Jeśli dodatkowo weźmiemy pod

8 Opis założeń, przebiegu oraz rezultatów eksperymentu znaleźć można w opracowaniu Ś w i d ó w (1961). Pisze o tym również Bogdan N o w a k (2008) w zbiorowej publikacji Szczypiorno penitencjarne... 
uwagę to, że wielu młodocianych było faktycznymi analfabetami - to wartość poznawcza uzyskanych drogą ankiety wyników badań jest bardzo wątpliwa.

Wnioski płynące z ,wyników badań" prowadzonych w tamtym okresie często wynikały z intuicyjnej wiedzy „badaczy”, ich własnych doświadczeń życiowych (zawodowych) oraz osobistych poglądów. Wywody te często obejmowały charakterystykę założeń organizacyjno-regulaminowych bez ukazywania głębszych mechanizmów funkcjonowania określonych aspektów odbywania kary pozbawienia wolności, a także bez wskazywania na przeszkody i niebezpieczeństwa tkwiące w strukturze i relacjach społecznych w zakładzie karnym. W rezultacie prowadziło to do afirmowania istniejących rozwiązań organizacyjno-regulaminowych oraz do formułowania naiwnych i mających życzeniowy charakter wniosków, takich jak: „przestępca, który zetknął się z dolegliwością kary, będzie strzegł się przed popełnieniem nowych przestępstw" (R u d nik 1970: 26).

W okresie powojennym ukazują się opracowania naukowe poświęcone problematyce resocjalizacji penitencjarnej, jednakże rozważania w nich zawarte mają aspekt prawny. Poza nielicznymi wyjątkami (Wa lig ó r a 1974; S i k or a 1978; K o s ew ski 1977) monografie naukowe poświęcone problematyce więziennej w oparciu o prowadzone badania własne nie były obecne. Instytucjonalne funkcjonowanie osób przestępczych analizowane było w dwóch zasadniczych wymiarach: podkultury więziennej i trudności (czy procesów) adaptacyjnych do warunków izolacji więziennej. Analizowane dane to „wyniki badań ilościowych, prowadzonych metodami dającymi ścisłe rezultaty wyrażające się liczbami" (K o s e w s k i 1985: 78). Sami autorzy przyznają, że stosowane standardowe metody badań psychologicznych nie były wystarczające i wymagały uzupełnień o nowe narzędzia i sposoby ich analizy (K o s e w s k i 1985: 79-80). Pewne odstępstwo od tradycyjnych, ilościowych metod zbierania i analizowania danych empirycznych widać jedynie $\mathrm{w}$ nieco późniejszych pracach Moczydłowskiego (1988).

Dopiero w latach 90. powstaje stosunkowo wiele opracowań, w tym monografii naukowych dotyczących rzeczywistości społecznej świata więziennego. Zmienia się także charakter oraz obiekt badań. Prowadzone są badania nie tylko w grupie więźniów, ale i wśród funkcjonariuszy. Także i ten zaniedbany przez wiele lat przedmiot badań naukowych doczekał się dociekliwych charakterystyk i analiz. W końcu zaś traci swoisty monopol ilościowa metodyka zbierania danych.

Zjawiska związane z instytucjami resocjalizującymi domagają się nowych wyjaśnień i trudno jest je wpisać $\mathrm{w}$ istniejące paradygmaty teoretyczno-metodologiczne. Niektórzy badacze podkreślają (M i s zew ski 2005; K a mińs ki 2006), że zastosowanie „tradycyjnej” metodyki zbierania danych (gdzie badacz zmierza do zweryfikowania określonych teorii i posługuje się narzędziami wystandaryzowanymi, kwestionariuszami z kafeterią zamkniętą itp.) z wielu względów nie jest właściwe, a nawet możliwe. 


\section{TRUDNOŚCI W PROWADZENIU BADAŃ NAUKOWYCH NA TERENIE ZAKŁADU KARNEGO}

Splot niekorzystnych czynników utrudniających proces badawczy tkwi zarówno w formalnej, jak i nieformalnej strukturze instytucji więziennej. W trakcie realizacji projektów badawczych na terenie zakładu karnego, ujawniają się liczne trudności i kumulują czynniki, które można podzielić na trzy grupy: 1) tkwiące w organizacji jednostki penitencjarnej, 2) w osobach badanych oraz 3) w osobie badacza. To wszystko z kolei implikuje określone problemy i ograniczenia natury metodologicznej.

Pierwsza grupa czynności wiąże się z uwarunkowaniami historyczno-politycznymi, procedurami formalnymi oraz „medialnością” problemów występujących w jednostkach penitencjarnych.

Przedstawiona $\mathrm{w}$ pierwszej części niniejszego opracowania sytuacja hermetyczności środowiska więziennego utrzymywała się długo - do końca lat 80 . $\mathrm{Z}$ jednej strony więziennictwo kojarzone było narzędziem represji ustroju i miejscem wielu nadużyć, zaś z drugiej budziło zaciekawienie i podejmowano próby łamania sztywnych ram tajności. Także współcześnie, w sytuacji przeświadczenia społecznego o braku skutecznej polityki przeciwdziałania przestępczości oraz postaw zorientowanych na surowe karanie przestępców ${ }^{9}$, ujawniają się skrajne uczucia społeczeństwa w odniesieniu do więziennictwa. Po pierwsze, jest to uzasadnione historycznie ,przeczulenie” na wszelkie objawy zniewolenia, po drugie - są to negatywne uprzedzenia do przejawów liberalizmu wobec przestępców „kryminalistów” odbywających kary pozbawienia wolności.

Wspomniana „medialność” problemów może więc być różnie rozumiana. Między innymi w konsekwencji wieloletniego tabu, jakie otaczało zakłady karne, społeczeństwo jest wyczulone na wszelkie informacje pochodzące zza murów więzienia, media rozpisują się na tematy związane $\mathrm{z}$ funkcjonowaniem jednostek penitencjarnych, a każde uchybienia i wątpliwości podlegają ostrej krytyce medialnej. „Medialność” problemów występujących na terenie jednostek penitencjarnych niesie z sobą praktyczne przeszkody także dla potencjalnego badacza. Gdy mass media nagłaśniają określone informacje związane np. z samobójstwem ważnego świadka w sławnym procesie, a do tego poddają w wątpliwość okoliczności tego wydarzenia, w praktyce podwyższa to pewnego rodzaju stan mobilizacji wszystkich jednostek penitencjarnych, które przybierają postawę gotowości na potencjalne kontrole lub bezpośrednie ataki reporterów itp. Powoduje to chociażby, że odpowiednio wcześniej zorganizowane i umówione spotkania badawcze na terenie zakładu karnego zostają odsunięte i zakwalifikowane do kategorii spraw, które „mogą poczekać”. Stwarza to określone opóźnienia, rozciągnięcia w czasie

9 Wskazują na to m.in. wyniki badań sondażowych CBOS (Opinie o funkcjonowaniu..., 1999; Kontakty z prawem... 2008). 
(np. pomiędzy poszczególnymi sesjami przeprowadzanych wywiadów) i wprowadza dysharmonię $\mathrm{w}$ proces postępowania badawczego. W tym miejscu należy wspomnieć o jeszcze jednym aspekcie, który można zakwalifikować do grupy „medialnych” (budzących zainteresowanie). Aktualnie dużą popularnością cieszą się kierunki pedagogiczne i psychologiczne o specjalnościach resocjalizacyjnych i sądowo-penitencjarnych. W rezultacie, każdego roku ogromna rzesza studentów ostatnich lat studiów I i II stopnia przygotowuje i realizuje własne projekty badawcze, których efekty będą przedstawione w pracach dyplomowych. Znaczna część studentów podejmuje problemy związane $\mathrm{z}$ funkcjonowaniem więźniów w zakładach karnych. Również w przeważającej części podejmowane przez studentów tematy prac badawczych dotyczą zagadnień wielokrotnie już analizowanych i prezentowanych w literaturze naukowej przedmiotu. Każdego roku więc do jednostek penitencjarnych trafia wielu studentów, którzy wyrażają chęć prowadzenia badań (najczęściej ankietowych) wśród więźniów. Dyrektorzy jednostek penitencjarnych coraz mniej chętnie wyrażają zgodę na realizację podobnych inicjatyw studenckich. Zasadnicze przeszkody nie tkwią w zwiększonym przy tej okazji nakładzie pracy funkcjonariuszy SW, ile w negatywnej postawie i niechęci potencjalnych badanych (więźniów) o czym będzie mowa jeszcze dalej ${ }^{10}$.

Jeśli badacz dotrze do środowiska więziennego, czeka go kolejne „wyzwanie" w postaci badanych - więźniów. Problemem jest kondycja psychospołeczna i sprawność intelektualna osób inkarcerowanych, a także ich właściwości osobowościowe i konsekwencje wynikające z przejawianego rodzaju i stopnia demoralizacji. Badacze zajmujący się negatywnymi następstwami izolacji społecznej nie są zgodni co do tego, czy i w jakim stopniu oraz zakresie podleganie izolacji więziennej negatywnie wpływa na funkcjonowanie intelektualne i psychiczne osadzonych. Oczywiście sytuacja ta nie pozostaje dla jednostki obojętna, jednakże charakter oraz zasięg tych oddziaływań nie jest jednoznacznie oceniany. Dominują poglądy, w myśl których konsekwencją izolacji więziennej są głębokie zmiany psychiczne. Klasyfikacje zaburzeń oraz opis związków przyczynowo-skutkowych znaleźć można m.in. w opracowaniach sprzed pół wieku autorstwa Grahama M. S yke s'a (1958). W Polsce, jeszcze w literaturze przedwojennej, znaleźć można rozważania dotyczące niekorzystnego wpływu osamotnienia społecznego w zakładzie karnym na funkcjonowanie człowieka. Jerzy S z p a k o w s k i w kwartalniku poświęconym zagadnieniom kryminologii i penitencjarystyki

10 Należy zwrócić uwagę, że przed podobnymi dylematami i problemami stawali dyrektorzy szkół, zwłaszcza gimnazjalnych, w okresie, gdy media alarmowały o agresji i przemocy międzyuczniowskiej. Media podsycały uwagę i zainteresowanie opinii publicznej tym problemem, co w konsekwencji powodowało, iż wielu badaczy (głównie w ramach projektów prac dyplomowych) podejmowało własne badania ankietowe dotyczące agresji wśród uczniów. Uczniowie „zasypywani” byli więc kwestionariuszami, w których dominowały powtarzające się fragmenty pytań dotyczących ich funkcjonowania szkolnego w kontekście doświadczania oraz stosowania agresji i przemocy. Nie należy się dziwić, iż dyrektorzy wielu szkół z ogromną ostrożnością i niechęcią wyrażają zgodę na prowadzenie podobnych badań. 
z 1936 r. wskazywał na szereg zaburzonych zachowań psychicznych, społecznych, a nawet zdrowotnych będących doświadczeniami osób uwięzionych. Wiele uwagi zjawisku poświęcali: Bogusław W a l i g ó r a (1974), Marek K o s e w s k i (1977), Krystyna K m i e cik-B aran (1992), Henryk Machel (2007) i in. Ciekawego przeglądu doniesień naukowych, polemizujących ze stanowiskiem większości naukowców o negatywnym wpływie izolacji więziennej na psychikę człowieka, dokonała Elżbieta J a n i s ze w s k a-Ta la g o (1980).

Należy dodać, że psychologiczne koncepcje wyjaśniające to zjawisko odwołują się do osiągnięć z zakresu psychologii stresu. Zasadniczym punktem wyjścia dla analiz jest stan deprywacji sensorycznej i jego oddziaływanie na organizm. $\mathrm{W}$ badaniach wpływu deprywacji na funkcjonowanie człowieka w warunkach izolacji eksperymentalnej stwierdza się występowanie kompleksu określonych zaburzeń różnorodnej natury. Większość z nich ustępuje po zakończeniu eksperymentu, część obserwuje się w określonym odcinku czasu nawet po ustaniu działania deprywacji. W kontekście tego podejścia i w odniesieniu do środowiska więziennego, na które składa się ubóstwo stymulacyjne, wymienia się głównie takie zaburzenia, jak: trudności w koncentracji, rozleniwienie intelektualne, zwiększona drażliwość, apatia, zaburzenia w zakresie schematu własnego ciała i oceny rzeczywistości, zakłócenia procesów myślenia, zaburzenia uwagi i funkcji intelektualnych oraz inne (za: Wa li g ó r a 1974). Prowadząc badania kwestionariuszowe należy być świadomym podobnych czynników, które mogą zniekształcić uzyskane dane. Najpełniejszą ich listę podaje Mo c zy dło w s ki $(1988,1989)$. Wśród najważniejszych są przede wszystkim niski poziom intelektualny badanych więźniów. Większość więźniów to osoby, które ukończyły szkoły podstawowe, ewentualnie ponadgimnazjalne ${ }^{11}$ i cechuje ich funkcjonalny analfabetyzm. Więźniów charakteryzują ponadto inne negatywne cechy, takie jak: poważne defekty osobowości uniemożliwiające badania ankietowe, psychopatie zaznaczające się z natury zawyżoną samoakceptacją, skłonnościami do manipulowania i kłamstwa, nawet bez możliwości uzyskania realnej korzyści. Moczydłowski donosił, że z setek rozdanych ankiet wraca do badacza zaledwie część, a i spośród tych znaczny procent stanowi niepełnowartościowy materiał $\mathrm{z}$ uwagi na niepełne wypełnienie lub ewidentne błędy (celowe lub niecelowe) w jej uzupełnianiu.

Częstym błędem popełnianym przez badacza jest niedostateczne uwzględnienie tych problemów, co skutkuje tym, że z uwagi na niskie kompetencje intelektualne więźniów wiele pytań jest dla nich niezrozumiałych bądź instrukcje wypełniania

11 Potwierdzają to liczne badania populacji więźniów. Np. dane przytaczane przez Aleksandrę S z y m a n o w s k ą (2003) pokazują, że ponad 5\% recydywistów nie posiada wykształcenia podstawowego, 56\% ukończyło szkołę podstawową, a jedna trzecia zasadniczą zawodową. Tylko $7 \%$ legitymuje się wykształceniem średnim i mniej niż $1 \%$ - wyższym. Iwona $\mathrm{N}$ i e w i a d o m s k a (2007) prowadziła badania w grupie recydywistów i nierecydywistów, spośród których ponad 1/3 ukończyła tylko szkołę podstawową, $42 \%$ - zasadniczą, natomiast $23 \%$ - średnią i zaledwie $1 \%$ legitymowało się wykształceniem wyższym. 
kwestionariuszy niejasne ${ }^{12}$. Moczydłowski wspomina również, że zdarzało się, że więźniowie informowali się nawzajem o badaniach i przyjmowali „wspólną wersję" wyników (zaznaczanych odpowiedzi).

Ponadto prowadzenie badań wśród więźniów może powodować ich niepokój i nieufność związaną z rzeczywistym celem wykorzystania zdobytych informacji. Marek K. K a mi ń s k i (2006: 22) ilustruje to zjawisko następującymi słowami:

Socjolog przeprowadzający badania w polskim więzieniu jest zazwyczaj mylony z psychologiem więziennym. Więzień uważa zazwyczaj socjologa lub psychologa za przedstawicieli administracji więziennej. Każda odpowiedź na zadawane pytania jest podyktowana własnym interesem więźnia [...] Podstawowe założenie wywiadu kwestionariuszowego przyjmowane implicite przez badaczy jest zatem w więzieniu często dramatycznie nieadekwatne: respondent nie jest jedynie beznamiętnym przekaźnikiem swoich opinii czy preferencji. Wręcz przeciwnie, jest bardzo mocno zainteresowany odbiorem swoich odpowiedzi przez badacza, ma silną motywację do deformowania przekazywanych informacji, a także spędza dużo czasu dopracowując techniki oszustwa i fikcyjne odpowiedzi na potencjalne pytania [...] Środowisko więzienia broni się przed poznaniem.

Kamil M is ze w s ki (2005) podważa przekonanie badaczy o tym, że więźniowie niechętnie uczestniczą $w$ badaniach przede wszystkim ze względu na „normy podkultury” - nakaz milczenia, niechęć do współpracy z personelem i osobami spoza środowiska przestępczego. Potocznie może wydawać się także, że osoby przebywające $\mathrm{w}$ wiezieniu przede wszystkim borykają się z nudą i cierpią na nadmiar czasu wolnego. Można więc przypuszczać, że wypełnianie ankiet może być sposobem na przerwanie monotonii: cóż do „roboty” mają więźniowie? Analiza doświadczeń opisanych przez Miszewskiego przeczy temu przekonaniu. Uważa on, że zasadniczy problem leży gdzie indziej, a mianowicie - konieczność wypełniania ankiet (brania udziału w badaniach) zaburza przyjęty rytm czasu w więzieniu ${ }^{13}$. Paradoksalnie najwłaściwszym określeniem będzie „brak czasu więźniów" na uczestniczenie w badaniach. Ponadto wskazuje na sygnalizowane już wcześniej zjawisko przesycenia badaniami ankietowymi.

12 Podobnych problemów doświadczyła autorka niniejszego artykułu prowadząc badania z zastosowaniem kwestionariusza wśród osadzonych w zakładzie karnym kobiet. Zastosowany kwestionariusz został odpowiednio zmodyfikowany, zwłaszcza w treściach instrukcji, wskazane były przykładowe sposoby zaznaczania odpowiedzi itp. Oprócz tego znaczna część kwestionariuszy została zwrócona niewypełniona, część z nich wypełniona pobieżnie i niedokładnie. Mimo iż kwestionariusz nie zawierał wielu pytań i potencjalny czas jego wypełniania zajmował 15 minut, znaczna część badanych tłumaczyła opóźnienia „brakiem czasu”. Innym charakterystycznym zjawiskiem było to, że chociaż zapewniano o anonimowości i o tym, że badane kwestie nie dotyczyły konkretnych sytuacji biograficznych wiele badanych osób podpisywało kwestionariusze imieniem, nazwiskiem, wskazywało na swoją datę urodzenia oraz imię ojca (S z c z e p a n i k 2007).

13 Problematyka postrzegania czasu, upływu czasu oraz przeżywanie „nadmiaru” czasu była m.in. przedmiotem rozważań Michała L e w a n d o w s k i e g o (1975). Jego opracowanie Pęknięcie ziemi stanowi głębokie studium nad nierealnością, nierzeczywistością i odmiennością czasu, doświadczania jego przemijania w warunkach izolacji więziennej. 
Paweł M o c z y dło w s k i (1988) podkreśla również bariery tkwiące w stosunku personelu więziennego wobec badań wśród więźniów. Co prawda jego doświadczenia sięgają jeszcze czasów, w których środowisko więzienne było objęte murem tajemnicy, ale współcześnie można próbować to odnieść do wspomnianego powyżej zjawiska „medialności” problemów występujących na terenie zakładów karnych. Według Moczydłowskieg o (1988: 88-89), poważne utrudnienia polegały na nieufności i podejrzliwości personelu, co do wykorzystania negatywnych opinii więźniów przeciwko niemu. W rezultacie dochodziło do sytuacji, gdy personel więzienny sabotował badania, np. określając je jako „sprzedawanie kryminału" przez więźniów. Moczydłowski spotykał się z kontrolowaniem przebiegu badań, wykorzystywaniem rozmaitych przepisów tak, aby rozmowy badaczy $\mathrm{z}$ więźniami przebiegały tylko w obecności personelu, który wywoływał celową dezinformację poprzez kierowanie rozmowy na inne tory, wyrażanie dezaprobaty „mową ciała” itp. Często nie wyrażano zgody na losowy dobór próby badawczej.

$\mathrm{Na}$ lęk funkcjonariuszy SW przed badaniami wskazuje również Dariusz Schmidt (1994), mimo iż przeprowadzał badania już w latach 90., czyli w okresie, gdy więzienia przestały (teoretycznie) stanowić miejsce niedostępne dla badawczy spoza resortu. Należy sądzić, iż obawy te związane są z lękiem o pozyskanie danych przez przełożonych oraz odczytanie ich jako skargi z ominięciem „drogi służbowej”. W takim razie, wobec przyznania się do wątpliwości, przejawianych problemów, słabości, wyciągnięte będą konsekwencje (nie bezpośrednie, ale w sposób systemowy), np. poprzez zmianę przepisów organizacji pracy na mniej korzystne.

W kontrolowaniu informacji przekazywanej badaczowi pomagają więźniowi techniki wypracowane przez subkulturę. Podobne uwagi czyni Kamil Mi s z ew s ki $(2005,2007)$, który powołuje się na własne doświadczenia więzienne podczas odbywania kary pozbawienia wolności. Według niego nawet współcześnie, w dobie większej otwartości jednostek penitencjarnych na badania naukowe, oszukiwanie badacza i tajenie przed nim informacji występuje również ze strony więźniów, jak i funkcjonariuszy. Zarówno więźniowie, jak i funkcjonariusze pragną przedstawić swoją grupę w jak najbardziej korzystnym świetle:

W więzieniu dzieje się wiele rzeczy, wobec których dyrekcja zakładu karnego nie chciałaby, by wieść o nich opuściła podległy jej teren. Oprócz spraw „ciężkiego kalibru”, jak korupcja funkcjonariusza, przejawiająca się np. w dostarczeniu osadzonemu telefonu komórkowego, umożliwienia nielegalnego kontaktu ze wspólnikiem przestępstwa czy wystawienia fałszywego, korzystnego dla osadzonego zaświadczenia o stanie zdrowia przez więziennego lekarza, które to sprawy w razie wykrycia kierowane są do prokuratury, występuje szereg innych, pomniejszych grzechów i grzeszków, które zazwyczaj stanowią tajemnicę poliszynela danej jednostki penitencjarnej i nie wychodzą poza jej mury (M is ze w s k i 2007: 46).

Trudności w realizacji projektów badawczych na terenie zakładów karnych mogą tkwić również w samej osobie badacza. Problemy te wiążą się z powyżej 
przedstawionymi kwestiami, jak np. bezkrytyczne zaufanie do narzędzi lub stosowanie metod badawczych nieadekwatnych ze względu na cechy badanej populacji. Badacze często nie są wolni od uprzedzeń i stereotypów, takich jak choćby związany z „nadmiarem czasu wolnego” osadzonych, o czym była mowa wcześniej. Trudności te tkwią także w konieczności uwolnienia się od założeń, teorii, które się „ma w głowie”, mogących zniekształcać zarówno uzyskiwane dane, jak i ich analizę. Stosowanie ,jakościowych" podejść badawczych wymaga więc wyzwolenia się od imperatywu formułowania koncepcji, założeń i punktów wyjścia oraz umiejętności i przyzwolenia na „bycie zaskoczonym” (por. U r b a n i a k-Z a j ą c, P i ek arski, red. 2001).

\section{DYLEMATY TAK ZWANEGO „JAKOŚCIOWEGO” PODEJŚCIA W BADANIU ŚRODOWISKA WIĘZIENNEGO}

Badania osób wykolejonych społecznie i przestępczych cechują się określoną specyfiką i niewątpliwie należy je sytuować w przestrzeni, w której badacz wchodzi w nowe i obce dla siebie środowisko kulturowe. Dlatego też w poznawaniu środowiska więziennego badacz napotyka takie same problemy metodologiczne, jak te, które związane są z przynależnością do innego kręgu kulturowego. Sytuacja taka stwarza poważne ograniczenia, chociaż może stanowić szanse na oryginalne odkrycia i analizy. Odnosząc się do poglądów Alfreda S c hüt za (1944), można powiedzieć, że badacz osiąga status „obcego”. Kulturowe wzory grupy, z której wywodzi się „obcy”, są efektem nieprzerwanego, historycznego rozwoju oraz częścią jego osobistej biografii. Stanowią one niebudzący wątpliwości schemat odniesienia do jego „względnie naturalnej koncepcji świata”. W konsekwencji „obcy” zaczyna interpretować nowe środowisko społeczne w kategoriach jego własnego myślenia zwyczajowego. W eseju The Stranger..., S chütz (1944) analizuje sytuację człowieka (emigranta), który znalazł się w obcym kulturowo otoczeniu. „Obcy” próbuje zrozumieć wzory kulturowe grupy, do której przybył, bada i rozpoznaje otoczenie. Dla „badacza” wszystko jest niejednoznaczne, niezrozumiałe, wymagające wytłumaczenia i uzasadnienia. Posiada wiedzę, którą nabył wychowując się w swojej własnej kulturze, własnej grupie i do niej automatycznie się odwołuje. W rezultacie zaczyna interpretować nowe środowisko społeczne w kategoriach jego własnego myślenia zwyczajowego. W obrębie systemu istotności wyniesionego z grupy pochodzenia odnajduje on gotowe wyobrażenie wzorów, które przypuszczalnie są obowiązujące w grupie, do której się zbliża. Jest to wyobrażenie, które wkrótce okazuje się nietrafne. Posiadana przez niego własna „wiedza kulturowa” nie jest przydatna w nowej sytuacji. Dlatego zadaje pytania, na które nie wpadłby „miejscowy”, od dzieciństwa nawykły do określonego stylu życia. Z drugiej strony może to skutkować negatywnymi konsekwencjami. Trafnie ilustrują tę sytuację słowa Mi s z ew s k i e g o (2005: 50): 
[...] rzeczywistość zakulisowa [nieformalna struktura więzienia - dop. R. Sz.] stawia barierę ontologiczną: nie wiemy nawet o co pytać. Stwarza to także pole dla badanych - świadomych tych trudności, którzy zaczynają manipulować dostarczanymi informacjami.

Środowisko przestępcze jest obce kulturowo badaczowi (por. doświadczenia opisane przez Mi s ze w s k i e g o (2005). Sam jest nie tylko „innym” i „obcym” - potencjalnym wrogiem i podejrzanym ${ }^{14}$, ale także tym, od którego można coś „ugrać”. M is z e w s ki (2005: 50-51) pisze o tym następująco:

Każdy z nas zapewne chciałby - stając się obiektem badań naukowych - wypaść w nich, jak najlepiej, jest to zupełnie zrozumiałe. [...] Od nich więc [więźniów - dop. R. Sz.] w ogromnym stopniu zależy, jaki wizerunek ich samych badacz przedstawi światu. Mają tu ogromną możliwość manipulacji i korzystają z niej: więźniowie na okrągło utyskują na zbyt wysokie wyroki i złe warunki w więzieniu, kreują się na ludzi skrzywdzonych przez prawo i jego egzekutorów, los itd. Badacz, który oprze swą opinię na wywiadach z osadzonymi, nie mający możliwości zweryfikowania ich wypowiedzi, staje się niezamierzenie ich rzecznikiem, jego analiza (wraz z podobnymi analizami innych badaczy) może np. przyczynić się do obniżenia kar w przyszłości. Jeśli zaś kary są nieadekwatnie niskie, wymiar sprawiedliwości przestaje być instytucją poważaną, przestępczość rośnie, itd.

Interesujące światło na problemy związane z prowadzeniem badań naukowych na terenie zakładów karnych rzucają opracowania autorstwa socjologów, którzy odbywali karę pozbawienia wolności. Ciekawą pozycją jest książka Marka M. K a mi ńs k i e g o (2006) Gry Więzienne. Tragikomiczny świat polskiego więzienia. Autor opisuje i interpretuje interakcje więzienne (m.in. rekonstruuje subkulturę grypsujących) w oparciu o teorię gier (,gdy jest konflikt interesów w grupie") - z zastosowaniem metody zbierania danych opartej na doświadczeniach własnych badacza ${ }^{15}$. Bezpośrednią inspiracją dla pracy badawczej była

${ }_{14} \mathrm{~K}$ a mińs ki pisze o tym następująco: „pomimo ogromnej ostrożności, dwukrotnie zostałem rozkminiony jako «socjolog, który notuje wydarzenia i prowadzi badania więzienne». Raz «przyznałem się», że rzeczywiście zamierzam napisać książkę i «opisać to wszystko», chociaż prawie nie zostałem aresztowany, tak jak wszyscy tutaj. Po chwili początkowej wrogości górę wzięła ciekawość, która przerodziła się w ekscytację projektem i chęć pomocy. Innym razem efektem rozkminienia było bicie. Wszystko to wydarzyło się, mimo że byłem autentycznym więźniem, że badanie było jedynie produktem ubocznym mojej roli i że dobrze znałem nie tylko więzienny język, ale i normy [...] Prowadzenie jakichkolwiek notatek w więzieniu jest niezwykle trudne. Więźniowie zabraniają opisywania czegokolwiek [...] i karzą za podejmowanie podobnych prób, interpretując je jako próby donosicielstwa" (K a m ińs k i 2006: 24, 25). Autor stosował różne wybiegi pozwalające mu na prowadzenie bieżących notatek, m.in. spisywał je w języku angielskim pod pretekstem nauki języka.

15 Kamiński trafił do więzienia w 1985 r. w związku ze swoją nielegalną działalnością w wydawnictwie podziemnym. Źródła swoich danych dzieli na następujące kategorie: doświadczenie przeżyć typowych dla więźnia; wielogodzinne i nieformalne rozmowy z więźniami; tajne szkolenie, przez które przechodzą wszyscy kandydaci na grypsujących; artefakty sztuki więziennej (piosenki, rysunki, listy itp.); wspomnienia i pisemne relacje więźniów politycznych i kryminalnych; raporty podziemnej Solidarności o stanie więziennictwa oraz oficjalne dane statystyczne. Dane zbierał w czasie 5 miesięcy pobytu w więzieniu. 
fascynacja przystosowywaniem się człowieka do funkcjonowania w warunkach ekstremalnych, jakie stwarza izolacja więzienna. Dla Kamińskiego była to

niesłychana elastyczność natury ludzkiej i zdolność moszczenia sobie życia w najbardziej dziwacznych sytuacjach [...] pragnąłem wyjść poza ograniczenia własnej roli więźnia politycznego i otworzyć się na otaczający świat. Chciałem zrealizować zamierzony z rozmachem i bez żadnych kompromisów projekt badawczy, wykorzystując trening metodologiczny wyniesiony z Instytutu Socjologii UW (K a m iń s k i 2006:16).

Przeżycie izolacji więziennej nie było dla autora wystarczające do opracowania materiałów, jakie stanowić mogłyby rzetelne źródło wiedzy o charakterze naukowym. Kamiński pisze o tym następująco:

[...] moje rozumienie życia więziennego i wspomnienie więźniów nie były pełne. Istniejąca literatura więzienna i wspomnienie więźniów oferowały fascynujące szczegóły i historie, ale nie były pomocne w rozumieniu ogólnych mechanizmów. Miałem pod ręką ogromny worek anegdot, ale brakowało mi zrozumienia zasad ogólnych (K a m iń s k i 2006: 17).

Zagadnienia związane z prowadzeniem badań na terenie zakładów karnych z pozycji „uczestnika” podejmuje także przywołany już Mis zewski (2005, 2007) i w sposób zdecydowany podważa wartość naukową badań kwestionariuszowych wśród więźniów. Autor podkreśla problemy metodologiczne związane przede wszystkim z przynależnością do innego kręgu kulturowego ${ }^{16}$. W artykule pod wymownym tytułem Socjolog w kryminale: więzienie jako nieprzyjazny teren badań (M is zew ski 2005) opisuje organizacyjne i metodologiczne problemy związane z pozyskiwaniem rzetelnych i obiektywnych wyników badań na terenie zakładu karnego. Ponadto pisze, że trudności w prowadzeniu badań na terenie więzienia „wydają się mieć charakter ponadczasowy, ponadkulturowy i uniwersalny [...] i związane są z istnieniem tej instytucji, jako totalnej" (M i s ze w s ki 2005: 90). Tak zwane „badania jawne” według Miszewskiego, zafałszowują wyniki, zwłaszcza gdy dotyczą „,rzeczywistości zakulisowej” (M i s z e w s k i 2007; por. So jak, Wic enty 2005: 173-212).

M iszewski (2005: 72) analizuje specyfikę więzienia jako terenu badań i wyraża przekonanie, że jedynie rzetelna jest obserwacja uczestnicząca i to wyłącznie w wariancie ukrytym. Przywołuje pogląd Roberta Mertona, w myśl którego większość instytucji posiada tzw. obszar świętości niedostępny dla osób z zewnątrz, głównie takich, którzy za pomocą nauki chcieliby go odkryć, zbadać (Merto n 1982; za: Mi s zew ski 2005). Trudności te analizuje także w kontekście takiej cechy podtrzymującej granice grupy, jak jej tajność. Tajności i jej funkcji społecznej poświęcił swoje rozważania George S i mmel (1975). Co

16 Odwołuje się do zasad badań terenowych w tradycji antropologicznej (P o t to n 1997), w której przyjmuje się, że uczestnik winien spędzić jako obserwator co najmniej 6 miesięcy w środowisku kultury, będącej przedmiotem jego obserwacji. Miszewski odbywał karę pozbawienia wolności 2 lata i 5 miesięcy za spowodowanie wypadku samochodowego. 
prawda, nie odnosił jej bezpośrednio do środowisk przestępczych, ale należy stwierdzić, że tajność i zasady tajności są zasadniczą i szczególnie cenioną cechą grupy społecznej, zwłaszcza zorganizowanej i wpisuje się w tzw. nieformalny kodeks honorowy, który posiada wbudowane mechanizmy ochrony wszelkich informacji. Pomijając kwestie związane z aktywnością przestępczą i ochroną informacji z obawy przed ingerencją organów ścigania i wymiaru sprawiedliwości, tajność dobitnie oznacza wykluczenie osób postronnych i - jak pisze S i m mel (1975: 415) - „odpowiednio uwydatnia poczucie posiadania czegoś na własność [...] w ten sposób wewnętrzna własność bez względu na jej wartość, sugeruje przekonanie, że to, czego wielu odmówiono, musi mieć wielką wartość". Już taka cecha powodować może niechęć do odkrywania przed badaczami wielu aspektów funkcjonowania przestępców (jako specyficznej grupy społecznej). Problemy te podnosił wspomniany wcześniej M oczydłowski (1988) - więźniowie (jak również personel więzienny) mieli wiele spraw, które chcieli ukryć, uczynić niedostępnym dla środowiska zewnętrznego. Owo ukrycie i niedostępność podnosiło wartość środowiska poddawanego próbie eksploracji. Wyrażało się to wprost - poprzez odmowę udziału w badaniach, bądź w sposób bardziej wyrafinowany, np. podawanie ustalanych wcześniej przez przywódców grupy fałszywych informacji.

Mis zewski (2007) rozważa kwestię przydatności metod jakościowych oraz ilościowych do badania „zjawisk trudnych” (zwłaszcza zakładu karnego) i analizuje pod tym kątem cztery możliwe sytuacje badacza środowiska: 1) badanie w sposób jawny danych jawnych; 2) badanie w sposób jawny danych ukrytych i brudnych oraz działań zakulisowych; 3) badanie w sposób ukryty danych jawnych oraz 4) badanie w sposób ukryty danych ukrytych i brudnych oraz działań zakulisowych. Wszystkie te podejścia podaje interesującej analizie pod kątem celowości i praktyczności zastosowania.

Metodą leżącą na przeciwnym biegunie w stosunku do badań sondażowych jest obserwacja uczestnicząca. Obserwacja uczestnicząca na gruncie nauk społecznych jest często wykorzystywana. Tę perspektywę metodologiczną przyjęli wymienieni wcześniej socjologowie Mikuszewski i Kamiński w badaniach środowiska więziennego. Obaj badali drugie życie instytucji, relacje w grupie więźniów itp. Rodowód obserwacji uczestniczącej sięga badań etnograficznych i antropologicznych. Wielu badaczy podnosi etyczne i metodologiczne zagrożenia stosowania obserwacji ukrytej uczestniczącej. Paweł Cho mczyński (2006) ukazuje dylematy moralne, jakie napotyka badacz, który zdecydował się na zastosowanie obserwacji uczestniczącej ukrytej. W odróżnieniu do obserwacji jawnej, gdzie autorzy badań wcześniej informują badanych o celu obserwacji i uzyskują od nich zgodę, obserwator stosujący technikę obserwacji ukrytej maskuje swoją „prawdziwą” tożsamość przed wszystkimi badanymi bądź niektórymi z nich. Konieczność godzenia ze sobą obydwu tożsamości - badacza i uczestnika fragmentu badanej rzeczywistości społecznej, jak również zobowiązań z nich wy- 
nikających, jest obciążająca moralnie (problem wzajemnego „zwierzania się”, zaufania, postawa badacza wobec konfliktu, angażowanie się weń, moment ujawnienia prawdziwej tożsamości). Zastosowanie obserwacji jawnej co prawda wyklucza problem oszustwa i związanych z nim dylematów etycznych - badani są świadomi roli swojej i badacza w procesie zbierania informacji, jednakże mają oni możliwość rozszerzania bądź ograniczania zakresu ujawnianych informacji. Chomczyński podjął także próbę wykazania wpływu doświadczanych trudności etycznych w stosowaniu obserwacji ukrytej na proces zbierania i interpretowania danych. Charakteryzuje obserwację ukrytą i przywołuje liczne poglądy jej zwolenników i przeciwników, którzy do głównych jej mankamentów zaliczają m.in. ryzyko niezamierzonego (czasami nawet nieświadomego) wpływu badacza na „obserwowaną” przez niego rzeczywistość, utratę obiektywizmu badacza w stosunku do przedmiotu badań, niemożność dokładnego zaplanowania swojej roli $\mathrm{w}$ trakcie obserwacji i angażowanie emocji badacza w stopniu trudnym do kontrolowania. W przedstawionych poglądach krytycznych przywołuje stanowisko Michaela P att o n a (1997), który wskazuje na jej bezużyteczność w przypadku grup, które funkcjonują na granicy bądź poza prawem, np. narkomani i przestępcy. Sytuację tę należy odnieść również do badań prowadzonych w warunkach izolacji więziennej. Badacze stosujący obserwację uczestniczącą ukrytą (M i s z e w sk i, 2005, 2007; K a m i ń s k i 2006) borykali się z rozmaitymi problemami natury organizacyjnej i moralnej - o czym była mowa we wcześniejszej części niniejszego opracowania $^{17}$.

\section{ZAKOŃCZENIE}

Badania prowadzone na terenie zakładu karnego, zwłaszcza wśród więźniów, mają wiele wad i towarzyszą im liczne dylematy bez względu na to, czy są to techniki kwestionariuszowe wywiady, czy prowadzone obserwacje. Ich rezultat bardzo często jest narażony na zniekształcenia wynikające ze specyfiki terenu badań oraz warunków, w jakich badanie się odbywa. Niektóre z nich wynikają z banalnej przyczyny - zdecydowana większość dorosłych przestępców to osoby niewykształcone, mające realne problemy z czytaniem ze zrozumieniem i pisaniem oraz werbalizowaniem myśli. Kolejne wysokie ryzyko - zebrane dane to celowo „wyprodukowane” przez więźnia informacje w celu otoczenia tajemnicą sposobów radzenia sobie z opresyjną codziennością życia w więzieniu. Podobne problemy towarzyszą różnym podejściom metodologicznym. Autorzy badań

${ }_{17} \mathrm{~K}$ a mińs ki (2006: 28) opisuje swoje starania asystowania przy wszystkich istotnych czynnościach w celi, a nawet inicjowanie pewnych sytuacji oraz łamanie rozmaitych norm subkulturowych i administracyjnych, by móc uzyskać cenne informacje. Konieczność zaniechania niektórych z nich była powodowana obawą przed dotkliwymi konsekwencjami i ochroną własnego bezpieczeństwa. 
wskazują na niezbędny aspekt sukcesu w realizacji projektów badawczych na terenie więzienia, jakim jest zdobycie minimum zaufania ze strony badanego (M o czydłowski 1988, 1989; Miszewski 2005; Ka miński 2006).

Badacza niezwiązanego ze środowiskiem więziennym spotykają dodatkowe utrudnienia natury organizacyjno-warsztatowej, które powinien wziąć pod uwagę planując badania w zakładzie karnym. Na przykład w przypadku wywiadów nie do końca wiadomo, jak w ostateczności zareaguje na nagranie badany więzień - może się zdarzyć, że w ostatniej chwili zmieni zdanie i powoła się na rozmaite artykuły prawne, które mają mu ewentualnie pomóc w postawieniu zarzutów, że badacz łamie jego prawa (szerzej: S z c z e p a n i k 2012).

Ponadto trzeba się oswoić ze środowiskiem więziennym, ograniczeniami przestrzennymi, swoistą atmosferą, która może negatywnie rzutować na samopoczucie badacza. Nie jest to naturalne otoczenie społeczne. Jest to środowisko nieprzyjazne, zamknięte, obwarowane sztywnością i zasadami, których należy bezwzględnie przestrzegać.

W odniesieniu do badań ,jakościowych”, wymagających bezpośredniego kontaktu badacza z badanym, najważniejszym utrudnieniem negatywnie rzutującym na proces pozyskiwania danych jest niemożliwość nawiązania naturalnego i bliskiego kontaktu. Atmosfera nacechowana jest z góry nieufnością i rezerwą, a „badanie” przebiega obustronnie. W przypadku osoby badanej mniej lub bardziej świadomie zaznaczają się rozmaite zachowania o charakterze manipulacyjnym, których głównym celem jest gra nastawiona na wyczuwanie granic pewności siebie badacza ${ }^{18}$, jego zaangażowania i motywacji, uzyskiwania jakiejś korzyści (jeśli nie materialnej, to wstawienia się u dyrektora lub wychowawcy, wystawienia jakiegoś certyfikatu, który można byłoby włączyć później do teczki osobowej w celu udokumentowania dobrego zachowania nastawionego na przedterminowe zwolnienie). Ponadto badany więzień odczuwa niepewność dotyczącą tego, czy i na ile określone, zebrane i zbierane dane mogą być przez badacza wykorzystane w celach innych niż naukowe oraz czy i na ile rozmowa $z$ badaczem nie będzie analizowana np. przez innych więźniów w kategoriach współpracy, konfidencji itp. Trudno więc o naturalność, sprzyjającą swobodnej i autentycznej narracji podczas prowadzenia wywiadu w warunkach więzienia.

$\mathrm{Na}$ realizację projektu badawczego w warunkach izolacji więziennej składać się winno nie tylko odpowiednie przygotowanie zaplecza teoretyczno-metodologicznego przez badacza. W sam proces badawczy wpisuje się odpowiednia postawa oraz swoista zmiana, jakiej powinien podlegać badacz. Polega to na konieczności oswojenia się z otoczeniem więziennym, z badanymi, których zachowania i reakcje mogą być różnorodne. Naukowiec winien przyjąć postawę

18 Nieodpowiednio rozłożona w czasie dociekliwość i natarczywość w pytaniach może sprzyjać manipulacji ze strony badanego - w świadomości więźnia „cenność” jego informacji wzrasta i być może warto negocjować ich ,cenę”. 
z jednej strony nacechowaną życzliwością i elastycznością, z drugiej natomiast dystansem i nieprzekraczaniem granic swojej roli ${ }^{19}$. Budowanie i doskonalenie warsztatu badacza w specyficznych warunkach zakładu karnego wymaga od niego pewnego rodzaju gotowości na zmianę i kształtowania otwartości.

Zwłaszcza w wywiadach narracyjnych, gdzie zaciera się granica badacz-badany (na rzecz „partnerów” rozmowy) naukowiec, podobnie jak w czasie prowadzenia obserwacji ukrytej, musi odpowiednio „zachęcić” badanego do zwierzania się. Nieskuteczne jednak są zwykle działania jednokierunkowe. Musi on stosować się do społecznych standardów interakcyjnych, które wymagają od partnerów rozmowy naprzemiennego nadawania i odbierania komunikatów oraz znaczeń. Jeśli badaczowi zależy na poznaniu prywatnych, czasami wręcz intymnych przeżyć, sam często musi zainicjować proces ich ujawniania poprzez odniesienie się do własnych doświadczeń. Aby uniknąć wrażenia „ciągnięcia za język”, wychodzi niejednokrotnie od opisu własnych przeżyć biograficznych, by skłonić rozmówcę do porównań werbalizowanych publicznie. Postępuje wtedy w myśl reguły wzajemności, licząc na wymianę informacji i wzrastającą otwartość w kontaktach z badanymi (szerzej: C h o m c z y ń ski 2006).

Weryfikacji badacza podlegają osobiste przekonania i stereotypy, a także reakcje i zachowania, często podszyte określonymi, naturalnymi emocjami. Społeczny świat więzienia wywołuje ambiwalentne odczucia, zwłaszcza w przypadku szczególnie bezlitosnych zabójców i przestępców seksualnych. Jest to świat, który jednocześnie odpycha i przyciąga, przeraża i fascynuje ( $\mathrm{H}$ a re 2006) ${ }^{20}$. Z jednej strony mamy do czynienia z kryminalistami, którzy odbywają karę pozbawienia wolności za czyny często nacechowane okrucieństwem lub bestialstwem, niejednokrotnie wynikające $\mathrm{z}$ irracjonalnych pobudek. Z drugiej, w bezpośrednim kontakcie z więźniem świadomość ta ustępuje miejsca swoistemu zaskoczeniu i konstatacji, że rozmówca jest zwykłym człowiekiem, niewyróżniającym się niczym specjalnym od innych i nieposiadającym znamion widocznej patologii.

Badacz powinien uodparniać się w kontakcie z osobą przestępczą na rozmaite techniki wywierania wpływu. Ważną umiejętnością jest okazywanie szacunku bez ryzyka, że postrzegany on będzie jako słabość lub przejaw zachwytu dla opowiadanych przez więźnia historii (o charakterze „wielkościowym”).

19 Co jest trudne zwłaszcza w badaniach z zastosowaniem wywiadów narracyjnych, gdzie z założenia doprowadza się do „partnerstwa” rozmawiających, a granice badacz - badany są płynne i niewyraźne (zob. U r b a n i a k-Z a j ą c, P i e k a r s k i, red. 2001). Problemy towarzyszące fazom przeprowadzania wywiadu narracyjnego z więźniami zostały opisane w opracowaniu: S z c z e p a nik 2012.

$20 \mathrm{Na}$ Międzynarodowej Konferencji Naukowej: „Resocjalizacja - w stronę środowiska otwartego", która odbywała się 24-25 kwietnia 2006 r. w Akademii Pedagogiki Specjalnej w Warszawie, Kazimierz P o s p i s z y 1 (2006) prezentując swoją książkę Przestępstwa seksualne stwierdził, że opracowania dotyczące sprawców przestępstw budzących szczególną odrazę i potępienie społeczne (pedofilia, przestępstwa seksualne, seryjne morderstwa ze szczególnym okrucieństwem itp.) znajdują wielu czytelników i cieszą się niezwykłą popularnością na rynku wydawniczym. 
Więźniowie najczęściej są badani technikami kwestionariuszowymi pod kątem ich biografii związanej z przestępczością. Przyzwyczajeni do pytań na temat ich doświadczeń przestępczych, zwykle przedstawiają swój życiorys w utartych i stereotypowych ramach wyprodukowanych na potrzeby kontaktu z przedstawicielami wymiaru sprawiedliwości. Zwykle trzeba odsłuchać tego „oficjalnego życiorysu” nacechowanego sloganami i regułkami, które są „recytowane” przed sądem penitencjarnym. Owe biografie nacechowane są opisem sytuacji z zastosowaniem technik neutralizujących przestępczą działalność oraz licznymi aktami skruchy i żalu. To wszystko implikuje określone warunki oraz modyfikacje, jakim winien podlegać projekt badawczy (jego założenia, cele, kontekst teoretyczny, metodologia), jak również sam badacz.

\section{BIBLIOGRAFIA}

B e d y ń s k i Krystian (1988), Wybrane problemy historii SW w Polsce Ludowej, Centralny Zarząd Zakładów Karnych, Wydział Polityczny i Szkolenia, Kalisz.

B u 1 i c k i Józef (1981), Liceum Penitencjarne - szkoła dla ambitnych, „Gazeta Penitencjarna”, nr 4, s. I-VI.

C h o m c z y ń s k i Paweł (2006), Wybrane problemy etyczne w badaniach. Obserwacja uczestniczaca ukryta, „Qualitative Sociology Review”, Vol. 2, No. 1, s. 68-87.

C o x Verne C., P a u 1 u s Paul B., M c C a in Garvin (1984), Prison Crowding Research. The Relevance of Prison Housing Standards and a General Approach Regarding Crowding Phenomena, „American Psychologist”, No. 39, s. 1148-1160.

F a 1 k o w s k a Wanda (1981), Krajobraz po bitwie, „Przekrój”, nr 1913, s. 4-5.

Gó rn y Jerzy (1996), Elementy indywidualizacji i humanizacji karania w rozwoju penitencjarystyki, WSPS, Warszawa.

H a r e Robert D. (2006), Psychopaci sq wśród nas, Wydawnictwo „Znak”, Kraków.

J a n i s z e w s k a-T a l a g o Elżbieta (1971), Powrotność skazanych po odbyciu dlugoterminowych kar pozbawienia wolności, „Przegląd penitencjarny i Kryminologiczny”, nr 2, s. 59-65.

J a n is ze w ska-Tala g o Elżbieta (1980), Wykonywanie kar dtugoterminowego pozbawienia wolności, Instytut Badania Prawa Sądowego, Warszawa.

J a r z ę b o w s k a-B a z i a k Barbara (1972), Praca wychowawcza w zaktadzie karnym dla młodocianych, Wydawnictwo Prawnicze, Warszawa.

J a r z ę b o w s k a-B a z i a k Barbara (1973), Obrona pracy doktorskiej pracownika Ośrodka Badań Przestępczości, „Przegląd Penitencjarny i Kryminologiczny”, nr 1, s. 91-92.

J a r z ę b o w s k a-B a z i a k Barbara, M or a w s k i Janusz (1972), Poglądy na resocjalizację recydywistów w praktyce penitencjarnej. Raport z badań, „Przegląd Penitencjarny i Kryminologiczny", nr 1, s. 40-55.

K a m i ń s k i Marek M. (2006), Gry więzienne. Tragikomiczny świat polskiego więzienia, Oficyna Naukowa, Warszawa.

K m i e c i k-B a r a n Krystyna (1992), Osamotnienie a zdrowie psychiczne, "Zeszyty Naukowe Uniwersytetu Gdańskiego", Psychologia, nr 10.

K o l e n d a Krzysztof (1995), Klawisze i złodzieje, Polski Dom Wydawniczy, Warszawa.

Kontakty z prawem ocena instytucji prawnych i poczucie bezpieczeństwa Polaków (2008), CBOS, Warszawa. 
K o p k a Bogusław, M a d e j Krzysztof (2004), NIK za kratami, „Biuletyn IPN”, nr 3, s. 78-83.

K o s e w s k i Marek (1985), Agresywni przestępcy, Książka i Wiedza, Warszawa.

K o w a ls k a Barbara (1966), Problem więźniów - bylych wychowanków zakładów poprawczych, „Przegląd Penitencjarny”, nr 2, s. 41-55.

L a s o c i k Zdzisław (2003), Organizacja i zasady działania więziennictwa, [w:] System penitencjarny i postpenitencjarny w Polsce, T. Bulenda (red.), ISP, Warszawa, s. 191-223.

L e w a n d o w s k i Michał (1975), Pęknięcie ziemi, Czytelnik, Warszawa.

List ze Smutnej [b.d.w.], Dział Informacji Naukowej Wojewódzkiej i Miejskiej Biblioteki Publicznej im. J. Piłsudskiego w Łodzi, Łódź.

Machel Henryk (1997), Personel więzienny - zagadnienie kompetencji resocjalizacyjnej, [w:] Problem podmiotowości czlowieka w pedagogice specjalnej, H. Machel (red.), Wydawnictwo Uniwersytetu Gdańskiego, Gdańsk, s. 145-155.

M a c h e 1 Henryk (2007), Sens i bezsens resocjalizacji penitencjarnej-casus polski, Impuls, Kraków.

M a c i a s Zbigniew (1983), Przedsiębiorstwa i zaklady pracy więziennictwa $w$ dobie reformy gospodarczej, „Przegląd Penitencjarny i Kryminologiczny”, nr 4, s. 43-52.

M a nd u lew i c z Marek (1969), W Kamiennej Górze - młodociani, „Gazeta Penitencjarna”, nr 86, s. II.

M e r t o n Robert K. (1982), Teoria socjologiczna i struktura społeczna, PWN, Warszawa.

M i c h a 1 s k i Zbigniew (1981), Po strzałach w Bydgoszczy, „Gazeta Penitencjarna”, nr 21, s. 3.

M i s ze w sk i Kamil (2005), Socjolog w kryminale: więzienie jako nieprzyjazny teren badań, „Przegląd Socjologiczny”, nr 3, s. 65-92.

M i s z e w s k i Kamil (2007), Kiedy badacz jest tajnym agentem. O postrzeganiu niejawnej obserwacji uczestniczacej jako etycznie problematycznej, metodach badań ilościowych, zakulisowych wymiarach życia spolecznego i ich zwiazku ze wszystkim tym, o czym przed chwila, „Przegląd Socjologii Jakościowej”, vol. 3, nr 2, s. 33-62, http://www.qualitativesociology review.org /PL/archive_pl.php, 21.06.2011.

M o c z y d ł o w s k i Paweł (1988), Drugie życie w instytucji totalnej, IPSiR UW, Warszawa.

M oc zydłow sk i Paweł (1989), O sposobach wglądu w sekrety stosunków międzyludzkich. Przypadek instytucji totalnych, [w:] Poza granicami socjologii ankietowej, A. Sułek, K. Nowak, A. Wyka (red.), Instytut Socjologii UW, PTS, Warszawa, s. 31-59.

M o c z y d ł o w s k i Paweł (1994), Więziennictwo od systemu totalitarnego do demokratycznego, „Przegląd Więziennictwa Polskiego”, nr 8, s. 31-54.

Moczydłow sk i Paweł (2003), Więziennictwo w okresie transformacji ustrojowej w Polsce: 1989-2003, [w:] System penitencjarny i postpenitencjarny w Polsce, T. Bulenda, R. Musiadłowski (red.), ISP, Warszawa, s. 77-127.

M o r a w s k i Jacek (1969), Z badań skuteczności resocjalizacji młodocianych w rygorze obostrzonym, „Przegląd Penitencjarny”, nr 4, s. 25-41.

N a s i e r o w s k i Jerzy (1988), Zbrodnia i..., Wydawnictwo Korporacja Ha!Art, Warszawa.

N a u m o w i c z Henryk (1967), O niektórych metodach badań psychologicznych w kryminologii, „Przegląd Penitencjarny”, nr 4, s. 23-35.

N a z a r e w i c z Czesław (2008), Poskramiacze, „Polityka”, nr 47, s. 18-20.

$\mathrm{N}$ a z a r e w i c z Katarzyna (1990), Czarne dni senatorów, „Życie Warszawy”, nr 5, s. 4.

$\mathrm{N}$ i e w i d o m sk a Iwona (2007), Osobowościowe uwarunkowania skuteczności pozbawienia wolności, KUL, Lublin.

N ow a k Bogdan (2008), Zapomniany eksperyment, [w:] Szczypiorno penitencjarne (Dodatek penitencjarny), Urząd Miasta w Kaliszu, Kalisz, http://www.kalisz.pl/files/118950095246e 65818ed840/broszura_kalisia.pdf, 21.07.2011. 
O s t r i h a n s k a Zofia (1971), Samoagresja wielokrotnych recydywistów, „Przegląd Penitencjarny i Kryminologiczny", nr 2, s. 20-34.

O w s i a n y Emil (1989), Głosy zza murów, „Przegląd Tygodniowy”, nr 39, s. 6.

P a t t o n Michael Q. (1997), Obserwacja-metoda badań terenowych, [w:] Ewaluacja w edukacji, L. Korporowicz (red.), Oficyna Naukowa, Warszawa, s. 163-200.

P a w l a k Krzysztof (1999), Za kratami więzień i obozów, Wydawnictwo COSSW, Kalisz.

P e l c Jerzy (1981), Karmić sikorki, „Tygodnik Solidarność”, nr 8, s. 8.

P o d e m s k i Stanistław (1987), Ciskanie platerów, „Polityka”, nr 25, s. 5.

Polityka karna i penitencjarna w Polsce w okresie przemian prawa karnego (2005), Wydawnictwa Uniwersytetu Warszawskiego, Warszawa.

R u d n i k Mieczysław (1970), Warunki reedukacji młodocianych skazanych na krótkie kary pozbawienia wolności, „Zeszyty Naukowe Uniwersytetu Jagiellońskiego”, vol. CCXL.

S a n o c k i Władysław (1970), Postawa wobec badania a wyniki inwentarza osobowości, „Przegląd Penitencjarny", nr 3, s. 49-72.

S c h midt Dariusz (1994), Badanie instytucji totalnej. Ograniczenia i perspektywy, „Opieka - Wychowanie - Terapia", nr 1, s. 21-29.

S c h ü t z Alfred (1944), The Stranger: An Essay in Social Psychology, „American Journal of Sociology", Vol. 49, No. 6, s. 499-507.

S e i d l e r Barbara (1968), Recydywa, „Życie Literackie”, nr 15, s. 13.

S i k or a Jadwiga (1963), Zagadnienie recydywy w świetle badań psychologicznych, „Przegląd Penitencjarny", nr 1, s. 58-69.

S i k o r a Jadwiga (1967), Doniesienie wstępne z badań nad wptywem kary pozbawienia wolności na procesy resocjalizacji, „Przegląd Penitencjarny, nr 1, s. 54-60.

S i k o r a Jadwiga (1971), Środowisko więzienne a problemy resocjalizacji, „Przegląd Penitencjarny i Kryminologiczny", nr 3, s. 18-35.

S i k o r a Jadwiga (1978), Resocjalizacja więźniów, PWN, Warszawa.

S i m m e 1 Georg (1975), Obcy, [w:] Georg S i m m e 1, Socjologia, PWN, Warszawa, s. 504-512.

S k o t n i c k i Witold (1969), Formy wykorzystywania wolnego czasu w opinii więźniów, „Gazeta Penitencjarna", nr 69, s. 2.

S o b o ń s k i Krzysztof (2009), Przemiany polskiego więziennictwa w minionym pięćdziesięcioleciu na przykładzie historii Aresztu Śledczego w Łodzi, AHE w Łodzi, Łódź, (niepublikowana praca magisterska).

S o j a k Radosław, W in c e n ty Daniel (2005), Zagubiona rzeczywistość: o społecznym konstruowaniu niewiedzy, Oficyna Naukowa, Warszawa.

S o 1 s k a Hanna (1973), Leczenie choroby alkoholowej w zakładach karnych, „Przegląd Penitencjarny i Kryminologiczny", nr 1, s. 46-51.

Spoleczno-polityczne determinanty postępowania z osobami pozbawionymi wolności w Polsce okresu minionego półwiecza. Implikacje dla praktyki resocjalizacji penitencjarnej (2009), „Przegląd Badań Edukacyjnych", nr 9, s. 29-41.

S tę p n i a k Klemens (1993), Stownik tajemnych gwar przestępczych, Puls, Londyn.

S y k e s George M. (1958), Society of Captives, Princeton University Press, Princeton.

S z c z e p a n i k Renata (2007), „Kobiecość” i „meskość” kobiet-sprawczyń rozbojów, [w:] Zachowania dewiacyjne dziewcząt i kobiet, I. Pospiszyl, R. Szczepanik (red.), Wydawnictwo AHE w Łodzi, Łódź, s. 57-70.

S z c z e p a n ik Renata (2009), Spoleczno-polityczne determinanty postępowania z osobami pozbawionymi wolności w Polsce okresu minionego pótwiecza. Implikacje dla praktyki resocjalizacji penitencjarnej, „Przegląd Badań Edukacyjnych”, nr 9, s. 29-41.

S z c z e p a n i k Renata (2012), Zastosowanie techniki wywiadu narracyjnego $w$ badaniach więźniów, „Resocjalizacja Polska”, nr 3, s. 89-105. 
S z p a k o w s k i Jerzy (1936), Z psychologii przeżyć więziennych, „Przegląd Więziennictwa Polskiego", z. 2, (Kasa Wzajemnej Pomocy Funkcjonariuszy Straży Więziennej), s. 17-39.

S z y m a n o w s k a Aleksandra (2003), Więzienie i co dalej, Wydawnictwo „Żak”, Warszawa.

S z y m a n o w s k i Teodor (1986), Podstawowe kierunki rozwoju systemu penitencjarnego w Polsce, „Archiwum Kryminologii”, vol. 13, s. 173-221.

Ś w i d a Hanna, Ś w i d a Wacław (1961), Młodociani przestępcy w więzieniu, Wiedza Powszechna, Warszawa.

Ta r a s z k i e w i c z Witold, Wo d n i c k i Bogdan (1957), Organizacja więziennictwa, „Biuletyn Ministerstwa Sprawiedliwości”, nr 2, s. 3-9.

U r b a n i a k-Z a ją c Danuta, P i e k a r s k i Jacek (red.) (2001), Jakościowe orientacje w badaniach pedagogicznych. Studia i materiały, Wydawnictwo Uniwersytetu Łódzkiego, Łódź.

W a 1 i g ó r a Bogusław (1974), Funkcjonowanie człowieka w warunkach izolacji więziennej, Wydawnictwo Naukowe UAM, Poznań.

W a n t u $\nmid$ a Hanna (1997), Abolicjonizm więzień - podejście racjonalne i humanitarne, Akademia Ekonomiczna w Krakowie, Kraków.

W i e r z b i c k i Piotr (1988), Rozwój penitencjarystyki w PRL, Wydawnictwo Prawnicze, Warszawa.

Z m a r z l i k Joanna (1981), Życie codzienne skazanego, „Tygodnik Solidarność”, nr 8, s. 8.

\section{Renata Szczepanik}

\section{CONDUCTING RESEARCH IN THE CONDITIONS OF PRISON}

Difficulties in implementing research projects in the correctional facility consists of many of factors. They connected with the organization penitentiary unit, sequentially with the persons studied, and with the person of the researcher. All this causes certain problems and limitations of methodological nature. In a negative way may affect the reliability and value of the cognitive test results obtained in particular survey. The purpose of this article is to investigate some difficulties in conducting research in prison conditions and methodology.

Keywords: prison, research in prisons, survey methods, analysis of qualitative data, the reliability of research results, the adequacy of research methods, study of total institutions. 